\title{
ORIGINALARTICLE
}

\section{Interval mapping of growth quantitative trait loci in Japanese Black beef cattle using microsatellite DNA markers and half-sib regression analysis}

\author{
Aduli Enoch Othniel MALAU-ADULI, ${ }^{1}$ Tomomi NIIBAYASHI, ${ }^{2}$ Takatoshi KOJIMA, ${ }^{2}$ Kazunaga OSHIMA, ${ }^{2}$ \\ Yasushi MIZOGUCHI ${ }^{3}$ and Masanori KOMATSU ${ }^{1}$ \\ ${ }^{I}$ National Institute of Livestock and Grassland Science, Tsukuba-shi, ${ }^{2}$ National Agricultural Research Center for \\ Western Region, Oda-shi and ${ }^{3}$ Shirakawa Institute of Animal Genetics, Nishigo-mura, Fukushima-ken, Japan
}

\begin{abstract}
A confirmatory scan for the regions of bovine chromosome 1 segregating the quantitative trait loci (QTL) influencing birthweight, weaning weight, yearling weight, and preweaning and postweaning average daily gains was performed by genotyping half-sib progeny of four Japanese Black sires using microsatellite DNA markers. Data were analyzed by generating an F-statistic every $1 \mathrm{cM}$ on a linkage map by the regression of phenotype on the probabilities of inheriting an allele from the sire after adjusting for the fixed effects of sire, sex, parity and season of birth as well as age as a covariate. Permutation tests at chromosome-wide significance thresholds were carried out over 10000 iterations. A significant QTL for birthweight at $114 \mathrm{cM}$ was detected in the sire 2 family. This identification of a birthweight QTL in Japanese Black cattle may be useful for the implementation of marker-assisted selection.
\end{abstract}

KEYWORDS: growth, Japanese Black cattle, microsatellite markers, quantitative trait loci (QTL).

\section{INTRODUCTION}

Breeding beef bulls are evaluated by their growth rate and yearling weight because of the positive correlation between growth and carcass traits (Baik et al. 2003; Koch et al. 2004). Japanese Black is the main beef cattle breed in Japan and is revered as a producer of high-quality meat. The growth of this breed, as reflected by liveweight changes from birth to yearling age, is important for the early attainment of slaughter weight. Identifying quantitative trait loci (QTL) has the potential to significantly increase the rate of genetic improvement through implementation of marker-assisted selection (Macneil \& Grosz 2002). For traits that are difficult or expensive to measure, are lowly heritable, occur late in life or are determined postmortem, markerassisted selection may increase the rate of response relative to selection based on estimated breeding value alone (Davis \& DeNise 1998). Therefore, selection indices that include QTL with accurately estimated effects on growth traits could reduce the amount of lengthy and costly data collection by providing a means of genetic evaluation early in the life cycle.

Microsatellite DNA markers on genetic maps are used to identify inheritance patterns of linked segments of the genome in structured pedigree populations. Significant associations of the marker allele with the phenotype of interest suggest linkage of

Correspondence: Aduli Enoch Othniel Malau-Aduli, School of Agricultural Science, University of Tasmania, Private Bag 54, Hobart, Tasmania 7001, Australia. (Email: Aduli.MalauAduli@utas.edu.au)

Received 10 October 2003; accepted for publication 8 September 2004. 
the markers to QTL. The detection and mapping of QTL for birthweight, liveweight, growth and carcass traits in paternal half-sib families of Charolais $\times$ Brahman, Brahman, Piedmontese, Belgian Blue and Beefbooster cattle has been reported (Davis etal. 1998; Stone etal. 1999; Casas et al. 2000, 2003; Li et al. 2002, 2004a,b). The mapping of QTL is the first step towards the identification of genes and causal polymorphisms for traits of importance in agriculture (Seaton et al. 2002). There are ongoing collaborative studies on QTL mapping for carcass traits in Japanese Black cattle between the Livestock Improvement Association, Shirakawa Institute of Animal Genetics and 21 Prefectures in Japan (Mizoguchi 1998) and some preliminary results have been reported at conferences. A number of simulated and theoretical studies on markerassisted selection (Saito \& Iwaisaki 1996, 1997a,b; Saito et al. 1998), as well as mathematical modeling of QTL cluster effects in granddaughter design, multigroup and outbred populations (Matsuda \& Iwaisaki 2000, 2001a,b,c), have been published. Therefore in the present study, we report for the first time, the results of QTL analysis for growth traits in 112 half-sib progeny from four Japanese Black sires. Preliminary genome-wide scanning in our laboratory using only 30 animals (unpublished data) had suggested Bos taurus autosomes (BTA) 1, 2 and 5 as chromosomes containing segregating QTL that significantly influenced the growth traits in Japanese Black cattle. Stone et al. (1999) had also reported a significant QTL affecting birthweight on BTAl in Brahman $\times$ Hereford cattle. More recently, Kim et al. (2003) detected a significant QTL for yearling weight on bovine chromosome one (BTAl) in Angus $\times$ Brahman crosses. Comparative mammalian genomics reveal that BTAl is equivalent to the human chromosome 3 (http://bos.cvm.tamu.edu/ htmls/rhbovl.html), which has been demonstrated to harbour growth-regulating genes such as the growth hormone secretagogue receptor, also known as ghrelin (Shuto et al. 2002; Choi etal. 2003; Hosoda et al. 2003), glycogenin (Mu et al. 2001) and Pit-1 (Ohta et al. 1992; Hendriks-Stegeman et al. 2001). It is therefore justifiable to focus on BTA 1 in the scan for growth QTL in Japanese Black cattle. Our objective was to conduct a confirmatory scan for segregating QTL on BTAl that influence bodyweight at birth, weaning and yearling age, and average daily gain before and after weaning by genotyping more Japanese Black cattle.

\section{MATERIALS AND METHODS}

\section{Animals and management}

One hundred and twelve paternal half-sib progeny of four Japanese Black sires produced by artificial insemination at the Department of Livestock and Grassland Science, National Agricultural Research Center for Western Region, Oda, Shimane Prefecture, Japan, were genotyped. Routine management of the animals involved recording of weight at birth and monthly thereafter, until 18 months of age. Calves were allowed to suckle their dams in addition to being fed $1.5 \mathrm{~kg} /$ day per head of concentrate and $1 \mathrm{~kg} /$ day per head of corn silage until 5 months of age when they were weaned. After weaning, they were moved to the grower's barn and continued to be raised on concentrates $(37 \%$ corn grain, $39 \%$ rice bran, $17 \%$ soybean meal, $7 \%$ minerals) and corn silage until 10 months of age. Between 10 and 18 months of age, they were moved to another barn and fed intensively. The proportions of the ration on a dry matter basis were $61 \%$ corn grain, $34 \%$ soybean and corn glutein meal, $2 \%$ bran and 3\% minerals. For every $20 \mathrm{~kg}$ bag, this ration provided an estimated $21 \%$ crude protein, $3.5 \%$ crude fat, $5 \%$ crude fiber, $7 \%$ ash, $0.6 \%$ calcium, $0.40 \%$ phosphate and a total digestible nutrients of $77 \%$. From 18 to 24 months of age, breeding females were returned to the calving barn and the steers were moved to the fattening barn where they were raised primarily on "Mosa meal", a specially formulated fattening ration containing $77 \%$ corn and rye grain, $10.5 \%$ wheat and rice bran, $9 \%$ soybean oil meal and 3.5\% mineral supplement. At all ages, routine veterinary vaccinations and health checks were carried out.

\section{Extraction of genomic DNA}

Following the method of Sambrook et al. (1989) and described in detail elsewhere (Malau-Aduli et al. 2003), genomic DNA was extracted and prepared from blood leukocytes and sperm.

\section{Polymerase chain reaction (PCR)}

The PCR premix $(13 \mu \mathrm{L})$ comprised: $10.55 \mu \mathrm{L}$ of distilled water, $1.04 \mu \mathrm{L}$ of $2.5 \mathrm{mmol} / \mathrm{L}$ dNTP mixture (Takara, Shiga, Japan), $1.3 \mu \mathrm{L}$ of $10 \times$ buffer containing $15 \mathrm{mmol} / \mathrm{L} \mathrm{MgCl}_{2}$ and $0.11 \mu \mathrm{L}$ of $25 \mathrm{mmol} / \mathrm{L}$ of $\mathrm{MgCl}_{2}$. A primer $(12.5 \mathrm{pmol} / \mu \mathrm{L})$ of the microsatellite DNA markers, each of which was labeled with one of three different fluorescent labels, FAM, HEX and TET (supplied by the Shirakawa Institute of Animal 
Genetics, Fukushima, Japan, and based on the bovine genetic map at the US Meat Animal Research Center (Kappes et al. 1997; http://sol.marc.usda.gov)) was added to the PCR premix. Genomic DNA ( $1 \mu \mathrm{L} ; 20 \mathrm{ng}$ / $\mu \mathrm{L}$ ) was added, followed by $0.5 \mu \mathrm{L}$ of Taq polymerase enzyme $(0.75$ units $/ \mu \mathrm{L})$ containing $50 \%$ glycerol (Takara). The PCR plates were hotplate-sealed and subjected to PCR in a DNA thermal cycler. The annealing temperature settings were $50^{\circ} \mathrm{C}, 55^{\circ} \mathrm{C}$ and $60^{\circ} \mathrm{C}$.

\section{Genotyping}

Multiplex genotyping was carried out. Prior to genotyping, the PCR products were mixed with the markers, which could be genotyped simultaneously in combinations of $4 \mu \mathrm{L}$ of HEX, $1 \mu \mathrm{L}$ of FAM and $1 \mu \mathrm{L}$ of TET. Next, $0.8 \mu \mathrm{L}$ of the mixed PCR products was added to $4.5 \mu \mathrm{L}$ of DNA size marker, centrifuged for $1 \mathrm{~min}$ at $120 \mathrm{~g}$ and denatured using the PCR machine at a denaturing temperature of $94^{\circ} \mathrm{C}$ for $9 \mathrm{~min}$. The denatured products were subjected to electrophoresis and genotyping in an ABI 377 DNA Sequencer. A total of 82 informative microsatellite DNA markers were used for the genotyping (Table 1).

\section{Traits analyzed}

Offspring of the four sires born between 1997 and 2002 were evaluated for growth traits. Birthweight (BWT), weaning weight (WT6) and yearling weight (WT12) were measured in kilograms, and the preweaning average daily gain (PREWADG) and postweaning average daily gain (POSTADG) were computed in $\mathrm{kg} /$ day (SAS Institute 2002).

\section{QTL analysis}

We adopted the methods of Haley and Knott (1992), Knott et al. (1996) and De Koning et al. (1998, 2001) for the detection and mapping of QTL in half-sib populations using least squares simple regression. We used the QTL Express computer program with a web-based user interface (http://qtl.cap.ed.ac.uk/) developed by Seaton et al. (2002) and based on the methods of the previously mentioned researchers for the QTL analysis. The half-sib model of QTL Express run within and across sires, implemented the analysis in a two-step procedure. First, microsatellite DNA marker data on progeny and their common parent (sire) were combined in a multipoint approach to calculate the

Table 1 Informative microsatellite DNA markers used for genotyping the five Japanese Black cattle families and their relative map positions (cM)*

\begin{tabular}{|c|c|c|c|c|c|c|c|c|c|c|c|}
\hline Family & Marker & Position & Family & Marker & Position & Family & Marker & Position & Family & Marker & Position \\
\hline 1 & BMS 1928 & 6.9 & 2 & BM8139 & 8.2 & 3 & BMS2321 & 14.0 & 4 & BMS1928 & 6.9 \\
\hline 1 & BMS711 & 21.3 & 2 & TGLA57 & 46.2 & 3 & ILSTS 104 & 28.2 & 4 & BMS711 & 21.3 \\
\hline 1 & ILSTS 104 & 28.2 & 2 & BMS4012 & 51.0 & 3 & BMS4002 & 47.9 & 4 & TGLA57 & 46.2 \\
\hline 1 & MB055 & 32.0 & 2 & BMS4013 & 61.3 & 3 & BMS4012 & 51.0 & 4 & BMS4035 & 55.0 \\
\hline 1 & TGLA57 & 46.2 & 2 & BMS4001 & 64.7 & 3 & BMS4035 & 55.0 & 4 & BMS4029 & 61.3 \\
\hline 1 & BMS4012 & 51.0 & 2 & BM9019 & 67.5 & 3 & RME36 & 63.0 & 4 & BM9019 & 67.5 \\
\hline 1 & BMS4035 & 55.0 & 2 & BL26-1 & 77.7 & 3 & BM8246 & 76.2 & 4 & BMS4008 & 71.7 \\
\hline 1 & RM326 & 55.6 & 2 & BMS4006 & 79.4 & 3 & BMS 119 & 88.6 & 4 & BMS4048 & 76.2 \\
\hline 1 & RME36 & 63.0 & 2 & URB038 & 80.6 & 3 & BMS4019 & 98.8 & 4 & URB038 & 80.6 \\
\hline 1 & INRA049 & 67.5 & 2 & MCM130 & 83.3 & 3 & UWCA46 & 113.8 & 4 & BMS4010 & 87.1 \\
\hline 1 & BM65O6 & 69.2 & 2 & BMS4010 & 87.1 & 3 & BMS599 & 125.8 & 4 & BM864 & 88.2 \\
\hline 1 & URB038 & 80.6 & 2 & BM864 & 88.2 & & & & 4 & BMS1170 & 92.8 \\
\hline 1 & BMS4052 & 94.6 & 2 & BMS 1170 & 92.8 & & & & 4 & BMS4019 & 98.8 \\
\hline 1 & BMS4028 & 95.6 & 2 & BMS4028 & 95.6 & & & & 4 & BMS4011 & 102.1 \\
\hline 1 & BMS4040 & 98.8 & 2 & BMS4019 & 98.8 & & & & 4 & BMS4049 & 114.3 \\
\hline 1 & BMS1789 & 100.9 & 2 & BMS1789 & 100.9 & & & & 4 & BMS918 & 118.1 \\
\hline 1 & BMS4044 & 128.7 & 2 & BMS1939 & 104.1 & & & & 4 & BMS599 & 125.8 \\
\hline \multirow[t]{6}{*}{1} & BMS2263 & 135.1 & 2 & BMS4039 & 108.3 & & & & 4 & BMS4044 & 128.7 \\
\hline & & & 2 & BM3205 & 113.8 & & & & 4 & BMS922 & 135.5 \\
\hline & & & 2 & BMS599 & 125.8 & & & & & & \\
\hline & & & 2 & BMS4043 & 128.7 & & & & & & \\
\hline & & & 2 & BMS2263 & 135.1 & & & & & & \\
\hline & & & 2 & BMS4014 & 135.5 & & & & & & \\
\hline Total & 18 & & & 23 & & & 11 & & & 19 & \\
\hline
\end{tabular}

\footnotetext{
*Based on the bovine genetic map at the US Meat Animal Research Center (Kappes et al. 1997; http://sol.marc.usda.gov).
} 
probabilities of inheriting allele 1 or 2 from the sire at specific chromosomal intervals. These probabilities were combined into coefficients with values between 0.0 and 1.0. Second, the phenotypic data on progeny were regressed on these coefficients in a withincommon-parent regression analysis. A linear model containing the fixed effects of sire, sex, parity and season of birth, as well as age as a covariate, was fitted to the probability coefficients and phenotypic data. Appropriate $F$-statistic thresholds for a $P<0.05$ chromosome-wise type 1 error rate were generated by permutation test as described by Churchill and Doerge (1994), Doerge and Churchill (1996) (and applied to other half-sib studies by Spelman et al. 1996 and Vilkki et al. 1997). In determining significant thresholds, the QTL Express software (Seaton et al. 2002) computed both the $F$-statistics and the $F$-threshold at $P<0.05$ chromosome-wise level. QTL were classified as significant when the $F$-statistic exceeded the $F$-threshold indicating a marker-trait association. Finally, the bootstrap procedure of Visscher et al. (1996) was followed to estimate the confidence intervals of the QTL locations.

\section{RESULTS}

A scan for the chromosomal regions of BTAl segregating the QTL influencing BWT, WT6, WT12, PREWADG and POSTADG was performed by genotyping paternal half-sib progeny of four Japanese Black sires. Table 1 shows the number of informative microsatellite markers, their intervals and positions across the four Japanese Black sires. In sires 1, 2, 3 and 4, 18, 23, 11 and 19 markers spanning 135.1, 135.5, 125.8 and $135.5 \mathrm{cM}$, respectively, were informative. The number of alleles ranged from a minimum of 3 to a maximum of 9 .

Means and standard deviations of phenotypic data of the progeny across sires are shown in Table 2 and Table 3 shows the estimated regression coefficients of sire QTL (additive/allele substitution) effects and estimated QTL locations corresponding to the peak of $F$ statistics, as well as chromosome-wide 5\% thresholds and $95 \%$ confidence intervals for the growth traits across sires. A QTL at $114 \mathrm{cM}$ between the markers BMS4039 and BM3205 in sire 2 achieved chromosome-wide significance $(P<0.05)$. No other chromosomal regions were shown to contain QTL effects that reached chromosome-wide significance. Figure 1 is a graphical depiction of the map of the F-statistics in the four sires.

\section{DISCUSSION}

The early attainment of slaughter weight in beef cattle hinges on the growth potential of calves. Thus, BWT, WT6, WT12, PREWADG and POSTADG are important traits for the beef industry. However, the strong, positive genetic correlation of $0.5-0.58$ between BWT and WT12 (Grosz \& MacNeil 2001) suggests that young breeding bulls selected for increased postnatal growth potential are expected to also sire calves having greater BWT, resulting in increased risk of dystocia. On the other hand, selection of sires with genetic potential to reduce BWT would concurrently sacrifice the growth potential of the calves. Therefore, identifying genes affecting pre- and postnatal growth coupled with marker-assisted selection, has the potential to overcome this genetic antagonism by allowing selection for growth during specific developmental stages. This in effect, decreases both the incidence of dystocia and economic loss inherent to calving difficulty while minimizing any coincident effect on postnatal growth (Grosz \& MacNeil 2001).

The chromosome-wide significant $(P<0.05)$ QTL influencing BWT detected at $114 \mathrm{cM}$ between the microsatellite DNA markers BMS4039 and BM3205 within the confidence interval spanning 50-119.5 cM in sire 2 (Table 3, Fig. 1) confirms the report of Stone et al. (1999) that BTAl harbors putative QTL that

Table 2 Distribution of progeny across sires, sexes and the growth traits (means \pm standard deviation) of Japanese Black cattle

\begin{tabular}{lcccccccc}
\hline Sire & Males & Females & Total & BWT $(\mathrm{kg})$ & WT6 $(\mathrm{kg})$ & WT12 $(\mathrm{kg})$ & $\begin{array}{l}\text { PREWADG } \\
(\mathrm{kg} / \mathrm{day})\end{array}$ & $\begin{array}{c}\text { POSTWADG } \\
(\mathrm{kg} / \mathrm{day})\end{array}$ \\
\hline 1 & 22 & 18 & 40 & $34.73 \pm 4.70$ & $163.92 \pm 21.73$ & $300.85 \pm 31.80$ & $0.72 \pm 0.11$ & $0.76 \pm 0.18$ \\
2 & 24 & 12 & 36 & $33.97 \pm 4.75$ & $172.62 \pm 19.38$ & $284.67 \pm 34.14$ & $0.77 \pm 0.09$ & $0.70 \pm 0.19$ \\
3 & 10 & 9 & 19 & $28.68 \pm 5.13$ & $177.63 \pm 20.52$ & $299.95 \pm 33.55$ & $0.83 \pm 0.10$ & $0.62 \pm 0.14$ \\
4 & 8 & 9 & 17 & $28.71 \pm 3.32$ & $176.71 \pm 22.94$ & $283.59 \pm 29.12$ & $0.82 \pm 0.12$ & $0.56 \pm 0.20$ \\
\hline
\end{tabular}

BWT, birthweight; WT6, weaning weight; WT12, yearling weight; PREWADG, preweaning average daily gain; POSTADG , postweaning average daily gain. 
Table 3 Regression coefficients of sire QTL (allele substitution) effects, estimated QTL locations and chromosome-wide $F$-statistics for growth traits of Japanese Black calves

\begin{tabular}{|c|c|c|c|c|}
\hline Sire family & 1 & 2 & 3 & 4 \\
\hline \multicolumn{5}{|l|}{ BWT } \\
\hline$\beta \pm S E$ & $3.57 \pm 1.96$ & $3.70 \pm 1.58$ & $3.10 \pm 2.43$ & $-4.43 \pm 1.24$ \\
\hline Estimated QTL location (cM) & 61 & $114^{*}$ & 47 & 111 \\
\hline$F$-statistic & $3.32 \mathrm{NS}$ & 5.49 significant & $1.63 \mathrm{NS}$ & $12.71 \mathrm{NS}$ \\
\hline Likelihood ratio & 3.07 & 4.84 & 1.41 & 5.00 \\
\hline$F$-threshold $(P<0.05)$ & 9.1 & 5.41 & 11.69 & 17.30 \\
\hline $95 \% \mathrm{CI}(\mathrm{cM})$ & $40.0-119.0$ & $50.0-119.5$ & $40.0-125.0$ & $40.0-126.0$ \\
\hline \multicolumn{5}{|l|}{ WT6 } \\
\hline$\beta \pm S E$ & $-15.41 \pm 9.40$ & $15.59 \pm 7.92$ & $-15.97 \pm 8.86$ & $39.04 \pm 11.33$ \\
\hline Estimated QTL location (cM) & 14 & 18 & 125 & 59 \\
\hline$F$-statistic & $2.69 \mathrm{NS}$ & $3.87 \mathrm{NS}$ & $3.24 \mathrm{NS}$ & $11.87 \mathrm{NS}$ \\
\hline Likelihood ratio & 2.51 & 3.51 & 2.62 & 4.82 \\
\hline$F$-threshold $(P<0.05)$ & 9.11 & 10.19 & 13.59 & 30.22 \\
\hline $95 \%$ CI (cM) & $4.5-124.0$ & $13.5-132.0$ & $40.5-125.0$ & $40.0-129.5$ \\
\hline \multicolumn{5}{|l|}{ WT12 } \\
\hline$\beta \pm S E$ & $-21.40 \pm 14.45$ & $-34.82 \pm 15.12$ & $-18.49 \pm 15.82$ & $-55.35 \pm 21.87$ \\
\hline Estimated QTL location (cM) & 14 & 48 & 52 & 115 \\
\hline$F$-statistic & $2.19 \mathrm{NS}$ & $5.31 \mathrm{NS}$ & $1.37 \mathrm{NS}$ & $6.40 \mathrm{NS}$ \\
\hline Likelihood ratio & 2.06 & 4.69 & 1.20 & 3.35 \\
\hline$F$-threshold $(\mathrm{P}<0.05) 20.37$ & 9.31 & 6.22 & 12.63 & \\
\hline $95 \% \mathrm{CI}(\mathrm{cM})$ & $6.5-122.0$ & $40.0-132.0$ & $40.0-123.0$ & $42.0-131.0$ \\
\hline \multicolumn{5}{|l|}{ PREWADG } \\
\hline$\beta \pm S E$ & $-0.09 \pm 0.05$ & $0.07 \pm 0.04$ & $-0.09 \pm 0.04$ & $0.20 \pm 0.06$ \\
\hline Estimated QTL location (cM) & 14 & 18 & 125 & 59 \\
\hline$F$-statistic & $4.09 \mathrm{NS}$ & $3.61 \mathrm{NS}$ & $4.43 \mathrm{NS}$ & $11.70 \mathrm{NS}$ \\
\hline Likelihood ratio & 3.72 & 3.29 & 3.40 & 4.79 \\
\hline$F$-threshold $(P<0.05)$ & 4.25 & 4.43 & 12.94 & 32.16 \\
\hline $95 \% \mathrm{CI}(\mathrm{cM})$ & $13.0-122.0$ & $17.0-132.0$ & $40.0-125.0$ & $50.0-130.0$ \\
\hline \multicolumn{5}{|l|}{ POSTADG } \\
\hline$\beta \pm S E$ & $0.10 \pm 0.09$ & $-0.21 \pm 0.10$ & $-0.14 \pm 0.06$ & $0.18 \pm 0.06$ \\
\hline Estimated QTL location (cM) & 82 & 27 & 29 & 77 \\
\hline$F$-statistic & $1.25 \mathrm{NS}$ & $4.81 \mathrm{NS}$ & $5.20 \mathrm{NS}$ & $9.44 \mathrm{NS}$ \\
\hline Likelihood ratio & 1.20 & 4.29 & 3.87 & 4.24 \\
\hline$F$-threshold $(P<0.05)$ & 9.09 & 5.88 & 6.05 & 17.22 \\
\hline $95 \% \mathrm{CI}(\mathrm{cM})$ & $20.0-128.0$ & $20.0-132.0$ & $20.0-125.0$ & $20.0-132.0$ \\
\hline
\end{tabular}

${ }^{*}$ Chromosome-wide significance $(P<0.05)$ level QTL; 95\%CI, 95\% confidence intervals (based on the reduced model only).

BWT, birthweight; WT6, weaning weight; WT12, yearling weight; PREWADG, preweaning average daily gain; POSTADG, postweaning average daily gain; NS, not significant; QTL, quantitative trait loci; cM, centi-Morgan.

significantly increased BWT in Brahman $\times$ Hereford cattle. They also found that other growth-related QTL for WT6 and WT12 reached suggestive thresholds only on BTA1. Similarly, Kim et al. (2003) in their investigation of QTL for growth and beef carcass fatness traits in Angus $\times$ Brahman cattle, reported a significant QTL affecting WT1 2 in the interstitial region of BTAl. They also detected a total of 30 QTL with suggestive evidence for linkage and 4 other significant QTL on 19 chromosomes. Other researchers (Casas et al. 1998, 2000, 2003; Davis et al. 1998; Keele et al. 1999; Grosz \& MacNeil 2001; MacNeil \& Grosz 2002) have also investigated QTL affecting BWT, growth and carcass composition of beef cattle in the USA. Grosz and Mac-
Neil (2001) detected a QTL influencing BWT at the telomeric end of BTA2 located at $114 \mathrm{cM}$ in the interval between BM2113 and OarFCB11 microsatellite markers. Davis et al. (1998) reported significant QTL effects on BWT in five chromosomes: BTA5, BTA6, BTA14, BTA18 and BTA2 1 located at 90, 48, 42, 116 and $4 \mathrm{cM}$, respectively. MacNeil and Grosz (2002) detected QTL for liveweight on BTAl7 located at 52 cM Casas et al. (2003) detected putative QTL for BWT on BTAl, BTA2 and BTA3, and for WT6 on BTA29. Genotyping work in our laboratory is currently focusing on BTA2 and BTA5 as part of the ongoing, long-term goal of whole genome-scanning of more Japanese Black cattle. The identification of a QTL 

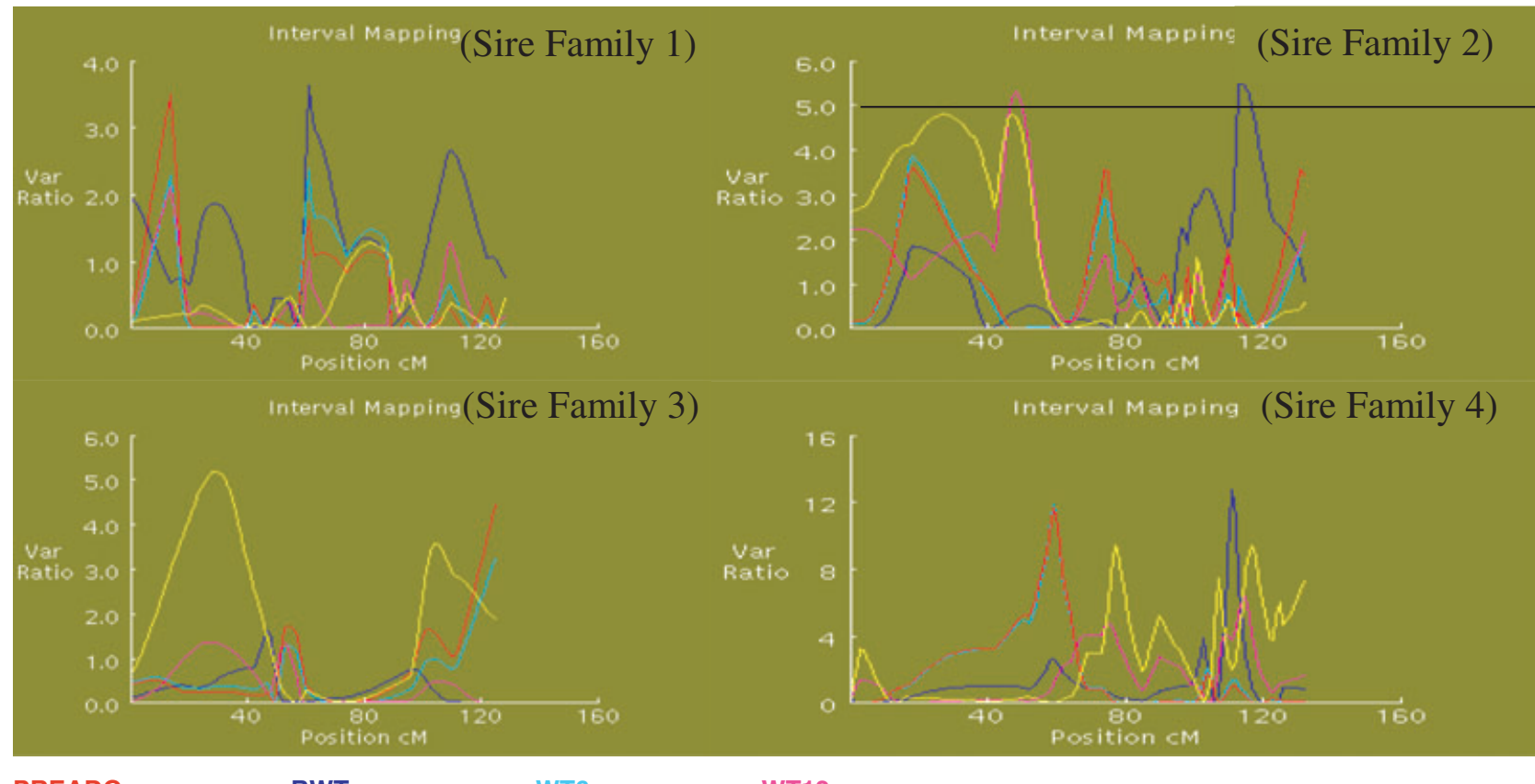

PREADG

BWT

WT6

WT12

Fig. 1 Map of the F-statistics in the four Japanese Black sire families. In sire 2 family, there is a significant (bold line) $P<0.05$ chromosome-wide threshold for birthweight.

in the present study indicates the presence of detectable segregation of alleles, hence a significant variation affecting an important trait (BWT) in Japanese Black cattle. This would be useful for the implementation of marker-assisted selection as an effective tool for the early attainment of slaughter weight in Wagyu cattle. Furthermore, this finding could pave the way for comparative candidate positional cloning in Japanese Black cattle using ghrelin, glycogenin or Pit-1 as candidate genes. The prospect of subsequently isolating and characterizing the genes using single nucleotide polymorphisms appears quite promising.

\section{ACKNOWLEDGMENTS}

This research was conducted when the senior author was at the Laboratory of Animal Breeding and Reproduction, National Agricultural Research Center for Western Region (WeNARC), Oda, Shimane Prefecture, Japan as a postdoctoral research fellow and we extend our appreciation to the Director of WeNARC. We are grateful to the Japan Society for the Promotion of Science for awarding their prestigious Post-Doctoral Research Fellowship in Bovine QTL Mapping to Dr A. E. O. Malau-Aduli. We thank Dr Yoshinori Sugimoto, Director of the Shirakawa Institute of Animal Genet- ics, Fukushima, for supplying us with the primer sets and we thank the Livestock Improvement Association of Japan Incorporated Tokyo, for supplying us with semen and sire blood samples. Our appreciation goes to Dr George Seaton of the Institute of Cell and Animal Population Biology, The University of Edinburgh, Scotland, for his useful advice on QTL Express.

\section{REFERENCES}

Baik DH, Hoque MA, Park GH, Park HK, Shim KS, Chung YH. 2003. Heritabilities and genetic correlations and sire and environmental effects on meat production potential of Hanwoo cattle. Asian-Australasian Journal of Animal Science 16, 1-5.

Casas E, Keele JW, Shackleford SD, Koohmaraie M, Sonstegard TS, Smith TPL, Kappes SM, Stone RT. 1998. Association of the muscle hypertrophy locus with carcass traits in beef cattle. Journal of Animal Science 76, 468-473.

Casas E, Shackleford SD, Keele JW, Koohmaraie M, Smith TPL, Stone RT. 2003. Detection of quantitative trait loci for growth and carcass composition in cattle. Journal of Animal Science 81, 2976-2983.

Casas E, Shackleford SD, Keele JW, Stone RT, Kappes SM, Koohmaraie M. 2000. Quantitative trait loci affecting growth and carcass composition of cattle segregating alternate forms of myostatin. Journal of Animal Science 78, 560-569. 
Choi K, Roh SG, Hong YH, Shrestha YB, Hishikawa D, Chen C, Kojima M, Kangawa K, Sasaki S. 2003. The role of ghrelin and growth hormone secretagogues receptor on rat adipogenesis. Endocrinology 144, 754-759.

Churchill GA, Doerge RW. 1994. Empirical threshold values for quantitative trait mapping. Genetics 138, 963-971.

Davis GP, Denise SK. 1998. The impact of genetic markers on selection. Journal of Animal Science 76, 2331-2339.

Davis GP, Hetzel DJS, Corbet NJ, Scacheri S, Lowden S, Renaud J, Mayne C, Stevenson R, Moore SS, Byrne K. 1998. The mapping of quantitative trait loci for birth weight in a tropical beef herd. In: Proceedings of the 6th World Congress on Genetics Applied to Livestock Production; 11-16 January 1998, Vol. 26, Armidale, Australia. pp. 441-444. Animal Genetics and Breeding Unit, University of New England, Armidale, Australia.

De Koning DJ, Visscher PM, Knott SA, Haley CS. 1998. A strategy for QTL detection in half-sib populations. Animal Science 67, 257-268.

De Koning DJ, Schulmant NF, Elo K, Moisio S, Kinos R, Vilkki J, Maki-Tanila A. 2001. Mapping of multiple quantitative trait loci by simple regression in half-sib designs. Journal of Animal Science 79, 616-622.

Doerge RW, Churchill GA. 1996. Permutation tests for multiple loci affecting a quantitative character. Genetics 142, 285-294.

Grosz MD, Macneil MD. 2001. Putative quantitative trait locus affecting birth weight on bovine chromosome 2 . Journal of Animal Science 79, 68-72.

Haley CS, Knott SA. 1992. A simple regression method for mapping quantitative trait loci in line crosses using flanking markers. Genetics 132, 1211-1222.

Hendriks-Stegeman BI, Augustijn KD, Bakker B, Holthuizen P, Van der Vliet PC, Jansen M. 2001. Combined pituitary hormone deficiency caused by compound heterozygosity for two novel mutations in the POU domain of the PITl/ POUlFl gene. Journal of Clinical Endocrinology and Metabolism 86, 1545-1550.

Hosoda H, Kojima M, Mizushima T, Shimizu S, Kangawa K. 2003. Structural divergence of human ghrelin: identification of multiple ghrelin-derived molecules produced by post-translational processing. Journal of Biological Chemistry 278, 64-70.

Kappes SM, Keele JW, Stone RT, McGraw RA, Sonstegard TS, Smith TPL, Lopez-Corrales NL, Beattie CW. 1997. A second generation linkage map of the bovine genome. Genome Research 7, 235-249.

Keele JW, Shackleford SD, Kappes SM, Koohmaraie M, Stone RT. 1999. A region on bovine chromosome 15 influences beef longissimus tenderness in steers. Journal of Animal Science 77, 1364-1371.

Kim JJ, Farnir F, Savell J, Taylor JF. 2003. Detection of quantitative trait loci for growth and beef carcass fatness traits in a cross between Bos taurus (Angus) and Bos indicus (Brahman cattle). Journal of Animal Science 81, 19331942.

Knott SA, Elsen JM, Haley CS. 1996. Methods for multiple marker mapping of quantitative trait loci in half-sib populations. Theoretical and Applied Genetics 93, 71-80.

Koch RM, Cundiff LV, Gregory KE, Van Vleck LD. 2004. Genetic response to selection for weaning weight or year- ling weight and muscle score in Hereford cattle: Efficiency of gain, growth and carcass characteristics. Journal of Animal Science 82, 668-682.

Li C, Basarab J, Snelling WM, Benkel B, Murdoch B, Moore SS. 2002. The identification of common haplotypes on bovine chromosome 5 within commercial lines of Bos taurus and their associations with growth traits. Journal of Animal Science 80, 1187-1 194.

Li C, Basarab J, Snelling WM, Benkel B, Murdoch B, Hansen C, Moore SS. 2004a. Assessment of positional candidate genes myf5 and igf 1 for growth on bovine chromosome 5 in commercial lines of Bos taurus. Journal of Animal Science 82, $1-7$.

Li C, Basarab J, Snelling WM, Benkel B, Kneeland J, Murdoch B, Hansen C, Moore SS. 2004b. Identification and fine mapping of quantitative trait loci for backfat on bovine chromosomes 2, 5, 6, 19, 21 and 23 in a commercial line of Bos taurus. Journal of Animal Science 82, 967972.

Macneil MD, Grosz MD. 2002. Genome-wide scans for QTL affecting carcass traits in Hereford $\times$ composite double backcross populations. Journal of Animal Science 80, 2316 2324.

Malau-Aduli AEO, Niibayashi T, Kojima T, Oshima K, Mizoguchi Y, Sugimoto Y, Komatsu M. 2003. Microsatellite DNA marker mapping of bovine chromosome one for QTL affecting birth weight and preweaning growth in Japanese Black cattle (Wagyu). In: Linda H (ed.), 50 Years of DNA: Proceedings of the Association for the Advancement of Animal Breeding and Genetics; Vol. 15, Melbourne, Australia. pp. 14-17. Animal Genetics and Breeding Unit, University of New England, Armidale, Australia.

Matsuda H, Iwaisaki H. 2000. Best linear unbiased prediction of QTL-cluster effects using flanking and upstream marker information in outbred populations. Japanese Journal of Biometrics 21, 39-49.

Matsuda H, Iwaisaki H. 200la. A mixed model method to predict QTL cluster effects using trait and marker information in a multi-group population. Genes and Genetic Systems 76, 81-88.

Matsuda H, Iwaisaki H. 200lb. Calculating elements of gametic relationship matrix in the model containing effects of marked QTL cluster. Japanese Journal of Biometrics 21, 41-51.

Matsuda H, Iwaisaki H. 2001c. Analytical solution to the expectation of identity-by-descent proportion for a chromosome segment conditional on marker data for half-sib family in granddaughter design. Animal Science Journal 72, 395-403.

Mizoguchi Y. 1998. QTL analysis of economic traits in Japanese Black cattle. In: Proceedings of the 5th Symposium of Animal Breeding and Genetics, pp. 9-14. Tokyo University, Tokyo, Japan.

Mu J, Skurat AV, Roach PJ. 2001. Glycogenin-2: a novel selfglucosylating protein involved in live glycogen biosynthesis. Journal of Biological Chemistry 276, 14532-14539.

Ohta K, Nobukuni Y, Mitsubuchi H, Ohta T, Tohma T, Jinno Y, Endo F, Matsuda I. 1992. Characterisation of the gene encoding human pituitary-specific transcription factor, Pit-1. Gene 122, 387-388. 
Saito S, Iwaisaki H. 1996. A reduced animal model with elimination of quantitative trait loci equations for marker-assisted selection. Genetic Selection Evolution 28, 465-477.

Saito S, Iwaisaki H. 1997a. A reduced animal model approach to predicting the total additive genetic merits for marker-assisted selection. Genetic Selection Evolution 29, 25-34.

Saito S, Iwaisaki H. 1997b. Back-solving in combined-merit models for marker-assisted best linear unbiased prediction of total additive genetic merit. Genetic Selection Evolution 29, 611-616.

Saito S, Matsuda H, Iwaisaki H. 1998. Best linear unbiased prediction of additive genetic merit using a combinedmerit sire and dam model for marker-assisted selection. Genes Genetic Systems 73, 65-69.

Sambrook J, Fritsch EF, Maniatis T. 1989. Molecular Cloning: A Laboratory Manual, 2nd edn. Cold Spring Harbor Laboratory Press, New York, USA.

Seaton G, Haley CS, Knott SA, Kearsey M, Visscher PM. 2002. QTL express: mapping quantitative trait loci in simple and complex pedigrees. Bioinformatics 18, 339340.
Shuto Y, Shibasaki T, Otagiri A, Kuriyama H, Ohata H, Tamura H, Kamegai J, Sugihara H, Oikawa S, Wakabayashi I. 2002. Hypothalamic growth hormone secretagogues receptor regulates growth hormone secretion, feeding and adiposity. Journal of Clinical Investigations 109, 1429-1436.

Spelman RJ, Coppieters WL, Karim A, van Arendok JAM, Bovenhuis H. 1996. Quantitative trait loci analysis for five milk production traits on chromosome six in the Dutch Holstein-Friesian population. Genetics 144, 1799-1808.

Statistical Analysis System (SAS) Institute. 2002. Statistical Analysis System. SAS Institute, Cary, NC, USA.

Stone RT, Keele JW, Shackleford SD, Kappes SM, Koohmaraie M. 1999. A primary screen of the bovine genome for quantitative trait loci affecting carcass and growth traits. Journal of Animal Science 77, 1379-1384.

Vilkki HJ, de Koning DJ, Elo KT, Velmala RJ, Maki-Tanila AV. 1997. Multiple marker mapping of quantitative trait loci of Finnish dairy cattle by regression. Journal of Dairy Science 73, 2525-2537.

Visscher PM, Thompson R, Haley CS. 1996. Confidence intervals in QTL mapping by bootstrapping. Genetics 143, 1013-1020. 